\title{
EVALUASI PELAKSANAAN PROGRAM PENGEMBANGAN \\ USAHA AGRIBISNIS PERDESAAN (PUAP) DI KABUPATEN TANJUNG JABUNG TIMUR
}

\author{
Siti Abir Wulandari \\ Fakultas Pertanian Universitas Batanghari Jambi \\ Email : abir_wulandari@yahoo.com
}

\begin{abstract}
Our government in this moment has distribute a relief fund program called PUAP (Program Usaha Agribisnis Pertanian) in order to develop the agribusiness entrepreneur in a village. Tanjung Jabung Timur (Tanjabtim) was one of regency that have received this program for four years, so that this regency was purposely chosed as a location of this research.

Sensus method had been use with 19 Gapoktans in its population. This research had been held in February to August which have two aims e.g. to know PUAP implementation ang the fund distribution by Gapoktan to the farmers. Secondary data was analyzed in this research that completed by direct information from the farmer.

The result of this research showed that this fund program called PUAP had been held in Tanjabtim since 2008 until 2012. The total fund Rp. 1.600.000.000 should be distribute for 16 villages. It's about Rp. 1.00.000.000 each Gapoktan. The average of fund that successfully distributed by Gapoktan to the farmers was Rp. 60.000.000. There was different numbers of Gapoktan's member and also they receive different amount of fund (its range was $R p$. 1.000.000 to $R p$. 5.000.000 per farmer). The fund return was ,paid by installments with $1,5 \%$ rate of interest.

It showed that The Gapoktan had distributed fund to the Farmer well but the farmer was failed to return it's fund and showed the fund was not develop yet. Keyword: PUAP, Farmer, Programs
\end{abstract}

\begin{abstract}
Abstrak
Saat ini pemerintah telah menyalurkan Bantuan Langsung Masyarakat PUAP yang selanjutnya disingkat BLM PUAP adalah dana bantuan modal untuk Gapoktan guna pengembangan usaha agribisnis di perdesaan. Propinsi Jambi merupakan salah satu propinsi yang mendapatkan program ini dimana pelaksanaannya masih berlangsung sampai tahun 2015. Kabupaten Tanjung Jabung Timur sebagai salah satu kabupaten yang menerima bantuan selama 4 tahun sehingga sengaja dipilih sebagai daerah penelitian.

Penelitian ini dilakukan secara sensus sehingga seluruh anggota populasi (19 Gapoktan ) menjadi sampel .Penelitian ini bertujuan untuk mengetahui bagaimana pelaksanaan program PUAP dan bagaimana penyaluran kredit oleh Gapoktan/LKMA kepada petani. Penelitian ini dilakukan pada bulan FebruariAgustus 2016. Penelitian ini menggunakan metode analisis data sekunder yang dilengkapi dengan survey lapangan, wawancara dengan responden

Hasil penelitian dapat disimpulkan beberapa kondisi bahwa program PUAP mulai bergulir di Kabupaten Tanjung Jabung Timur sejak tahun 2008 yang
\end{abstract}


dikucurkan untuk 16 desa dengan total dana sebesar Rp. 1.600.000.000,- Ratarata dana PUAP dari pemerintah sebesar Rp. 100.000.000,- per Gapoktan dengan rata-rata penyaluran per Gapoktan 60.000.000,-. Setiap gapoktan memiliki jumlah anggota dan besar penyaluran yang berbeda pula. Kisaran dana yang disalurkan ke petani sebesar Rp. 1.000.000,- Rp. 5.000.000,- per petani. Proses pengembalian dana dilakukan dengan mencicil ditambah uang jasa $1.5 \%$ dari pinjaman per bulan.

Proses penyaluran kredit oleh Gapoktan/LKMA kepada petani dapat dikatakan berhasil dengan adanya penyaluran yang mayoritas sudah mencapai Rp.60.000.000 ke atas, tetapi belum berhasil dalam perkembangan dananya.

\section{Kata kunci : PUAP, Petani, Program}

\section{PENDAHULUAN}

Sektor ekonomi terbesar dan terpenting dalam perekonomian nasional Indonesia adalah sektor pertanian. Sektor agribisnis menyerap lebih dari $75 \%$ angkatan kerja nasional termasuk di dalamnya 21,3 juta unit usaha skala kecil berupa usaha rumah tangga, maka sebesar $80 \%$ dari jumlah penduduk nasional menggantung hidupnya pada sektor agribisnis. Peranan sektor agribisnis yang demikian besar dalam perekonomian nasional memiliki implikasi penting dalam pembangunan ekonomi nasional ke depan (Saragih,1997).

Indonesia adalah negara agraris, sehingga semua masyarakat Indonesia tahu dan sadar bahwa bangsa Indonesia mempunyai potensi besar dalam sektor pertanian. Hal ini dapat dilihat dari mata pencaharian utama masyarakat Indonesia adalah bertani. Atau dapat dikatakan pula bahwa sebagian besar masyarakat Indonesia menggantungkan hidupnya dari sektor agraris baik untuk bercocok tanam, beternak, ataupun yang lainnya.

Salah satu program kebijakan pembangunan pertanian dalam rangka pengentasan kemiskinan, ketahanan pangan dan mewujudkan kesejahteraan petani dan pedesaan adalah program PUAP. Program Pengembangan Usaha Agribisnis Perdesaan (PUAP) merupakan program nasional dalam rangka pengentasan kemiskinan pada sektor pertanian yang telah dilaksanakan oleh Kementerian Pertanian Republik Indonesia sejak tahun 2008. Program ini berupa pemberian dana bantuan penguatan modal kepada petani melalui Gapoktan/LKMA. Petani diharapkan memanfaatkan dana tersebut untuk mengembangkan agribisnis mereka untuk meningkatkan pendapatan petani sehingga petani keluar dari kemiskinan.

Propinsi Jambi merupakan salah satu propinsi yang mendapatkan program ini dimana pelaksanaannya masih berlangsung sampai tahun 2015. Kabupaten Tanjung Jabung Timur sebagai salah satu kabupaten yang menerima bantuan tersebut sejak tahun 2008, hingga tahun 2012 sebanyak 87 gapoktan telah menerimanya. Dari uraian diatas penulis tertarik untuk melakukan penelitian dengan judul "Evaluasi Pelaksanaan Program Pengembangan Usaha Agribisnis Perdesaan (PUAP) Di Kabupaten Tanjung Jabung Timur".

Tahun 1972, (Era Orde Baru) pertama kali kebijakan bagi bangsa Indonesia meletakkan sektor pertanian sebagai landasan pembangunan bangsa. Hal ini mengingat peran strategis sektor pertanian dengan besarnya jumlah penduduk yang terlibat di dalamnya. Bahkan saat ini peningkatan penduduk di Indonesia 
justru akan menimbulkan permasalahan besar. Menurut data yang dipublikasi Badan Pusat Statistik (BPS 2015), persentase penduduk miskin di Indonesia mencapai 28,59 juta orang (11,22 persen), meningkat 0,86 juta orang dibandingkan pada tahun 2014. Dari uraian diatas maka dapat dirumuskan permasalahan sebagai berikut :

1. Bagaimana pelaksanaan program PUAP di Kabupaten Tanjung Jabung Timur?

2. Bagaimana penyaluran kredit oleh Gapoktan/LKMA kepada petani?

Tujuan dari penelitian ini adalah untuk mengetahui : Bagaimana pelaksanaan program PUAP di Kabupaten Tanjung Jabung Timur dan bagaimana penyaluran kredit oleh Gapoktan/LKMA kepada petani di Kabupaten Tanjung Jabung Timur.

\section{LANDASAN TEORI}

\section{Konsep Evaluasi}

Evaluasi adalah upaya untuk menilai proses pelaksanaan rencana, ada tidaknya penyimpangan dan tercapai tidaknya sasaran yang ditetapkan sesuai rencana yang telah dibuat, ditujukan pada suatu obyek tertentu dan periode tertentu (Rodjak, A. 1996). Berdasarkan buku pedoman PUAP, maka kriteria yang digunakan untuk mengevaluasi pelaksanaan program PUAP adalah: sosialisasi, penggunaan dana, manfaat, pembinaan, monitoring, sasaran/ penerima dana, pengembalian.

\section{Kredit dan Pinjaman Dana Bergulir}

Dalam Peraturan Menteri Keuangan yang dimaksud dana bergulir adalah dana yang dialokasikan oleh Kementerian Negara/Lembaga /SatuanKerja /Badan Layanan Umum untuk kegiatan perkuatan modal usaha bagi koperasi, usaha mikro, kecil, menengah, dan usaha lainnya yang berada di bawah pembinaan Kementerian Negara/Lembaga. Dalam Peraturan Menkeu tersebut diatur bahwa suatu dana dikategorikan sebagai Dana Bergulir jika memenuhi karakteristik : (i) merupakan bagian dari keuangan negara; (ii) dicantumkan dalam APBN dan atau laporan keuangan negara, (iii) dimiliki, dikuasai, dan atau dikendalikan oleh Pengguna Anggaran (PA) / Kuasa Pengguna Anggaran (KPA), (iv) disalurkan/dipinjamkan kepada masyarakat kelompok masyarakat, ditagih kembali dengan atau tanpa nilai tambah, dan digulirkan kembali kepada masyarakat kelompok masyarakat (revolving fund), (v) ditujukan untuk perkuatan modal koperasi, usaha mikro, kecil, menengah dan usaha lainnya, dan (vi) dapat ditarik kembali pada suatu saat (Permenkeu no.99/PMK.05/2008).

\section{Konsep Agribisnis}

Agribisnis adalah rangkaian kegiatan usaha pertanian yang terdiri atas 4 (empat) subsistem meliputi subsistem hulu, subsistem pertanian primer, subsistem agribisnis hilir, dan subsistem penunjang. Subsistem Hulu adalah kegiatan ekonomi yang menghasilkan sarana produksi (input) pertanian. Subsistem Pertanian Primer adalah kegiatan ekonomi yang menggunakan sarana produksi yang dihasilkan subsistem hulu. Subsistem Agribisnis Hilir adalah yang mengolah dan memasarkan komoditas pertanian. Subsistem Penunjang adalah kegiatan yang menyediakan jasa penunjang antara lain permodalan, teknologi dan lain-lain. (Soekartawi, 2006).

\section{Program PUAP}


Permasalahan mendasar yang dihadapi petani adalah kurangnya akses kepada sumber permodalan, pasar dan teknologi serta organisasi tani yang masih lemah. Pengembangan Usaha Agribisnis Perdesaan yang selanjutnya disingkat PUAP adalah bantuan modal usaha Gabungan Kelompoktani dalam menumbuhkembangkan usaha agribisnis sesuai dengan potensi pertanian desa sasaran. PUAP merupakan bentuk fasilitasi bantuan modal usaha bagi petani anggota, baik petani pemilik, petani penggarap, buruh tani maupun rumah tangga tani yang dikoordinasikan oleh Gabungan Kelompok Tani (Gapoktan). PUAP bertujuan untuk: 1. mengurangi kemiskinan dan pengangguran melalui penumbuhan dan pengembangan kegiatan usaha agribisnis di perdesaan sesuai dengan potensi wilayah; 2. meningkatkan kemampuan dan pengetahuan pelaku usaha agribisnis, pengurus Gapoktan, Penyuluh dan Penyelia Mitra Tani (PMT); 3. memberdayakan kelembagaan petani dan ekonomi perdesaan untuk pengembangan kegiatan usaha agribisnis; dan 4. meningkatkan fungsi kelembagaan ekonomi petani menjadi jejaring atau mitra lembaga keuangan dalam rangka akses ke permodalan.

Sedangkan Sasaran PUAP yaitu: 1. berkembangnya usaha agribisnis di desa terutama desa miskin sesuai dengan potensi pertanian desa; 2 . berkembangnya Gapoktan yang dimiliki dan dikelola oleh petani untuk menjadi kelembagaan ekonomi; 3. meningkatnya kesejahteraan rumah tangga tani miskin, petani/peternak (pemilik dan/atau penggarap) skala kecil, buruh tani; dan 4 . berkembangnya usaha agribisnis petani yang mempunyai siklus usaha.

Indikator keberhasilan output antara lain:

1. tersalurkannya dana Bantuan Langsung Masyarakat (BLM) PUAP 2015 kepada petani, buruh tani dan rumah tangga tani miskin anggota Gapoktan sebagai modal untuk melakukan usaha produktif pertanian; dan 2. terlaksananya fasilitasi penguatan kapasitas dan kemampuan sumber daya manusia pengelola Gapoktan, Penyuluh dan PMT.

Indikator keberhasilan outcome antara lain:

1. meningkatnya kemampuan Gapoktan dalam memfasilitasi dan mengelola bantuan modal usaha untuk petani anggota baik petani pemilik penggarap, petani penggarap, buruh tani maupun rumah tangga tani; 2 . meningkatnya jumlah petani, buruh tani dan rumah tangga tani yang mendapatkan bantuan modal usaha; dan 3 . meningkatnya aktivitas kegiatan usaha agribisnis (hulu, budidaya dan hilir) di perdesaan.

Sedangkan Indikator benefit dan Impact antara lain:

1. Berkembangnya usaha agribisnis di perdesaan; 2. berfungsinya Gapoktan sebagai lembaga ekonomi petani di perdesaan yang dimiliki dan dikelola oleh petani; dan 3. berkurangnya jumlah petani miskin dan pengangguran di perdesaan.

Luaran yang diharapkan dari penelitian ini adalah berupa informasi mengenai pengelolaan dana PUAP oleh petani sehingga pemerintah mengetahui sejauh mana keberhasilan program PUAP telah tercapai.

\section{METODOLOGI PENELITIAN \\ Ruang Lingkup Penelitian}

Penelitian ini dilakukan di Kabupaten Tanjung Jabung Timur Propinsi Jambi. Pemilihan Kabupaten Tanjung Jabung Timur ini dilakukan dengan sengaja karena Kabupaten Tanjung Jabung Timur selama 4 tahun berturut 
mendapatkan dana PUAP. Adapun yang menjadi fokus kajian dalam penelitian ini adalah evaluasi terhadap pelaksanaan program PUAP ditetapkan berdasarkan buku Pedoman Umum PUAP dan buku Pedoman dan Modul Pengembangan Lembaga Keuangan Mikro yang dikeluarkan oleh Kementerian Pertanian tahun 2010. Fokus kajian yaitu : sosialisasi, penggunaan dana, manfaat, pembinaan, monitoring, sasaran/ penerima dana, pengembalian.

\section{Sumber dan Metode Pengumpulan Data}

Jenis dan sumber data yang digunakan dalam penelitian ini adalah data primer dan data sekunder. Data primer adalah data yang dikumpulkan dari sumber data pertama. Data primer diperoleh melalui survey lapangan dan wawancara terhadap para petani di Kabupaten Tanjung Jabung Timur. Data sekunder merupakan data penunjang data primer yang diperoleh dari instansi terkait berupa laporan dan publikasi. Sumber data sekunder didapat dari Badan Pusat Statistik Kabupaten Tanjung Jabung Timur, jurnal-jurnal penelitian, dan publikasi yang mendukung penelitian ini. Data sekunder dikumpulkan dengan menggunakan studi kepustakaan.

\section{Metode Penarikan Sampel}

Penelitian ini dilaksanakan di Kabupaten Tanjung Jabung Timur, populasi dari penelitian ini adalah seluruh Gapoktan/LKMA pengelola dana bergulir PUAP yang menerima bantuan dana PUAP tahun 2012 dengan jumlah populasi 19 unit Gapoktan/LKMA yang tersebar pada 6 kecamatan. Pengambilan sampel dengan menggunakan teknik cluster sampling. Pada penelitian ini klaster yang dimaksud adalah . Pada masing-masing kecamatan diambil sampel secara proporsional dengan Proportional Allocation sebagai berikut :

Dimana :

$$
n i=\frac{N i}{N} \times n
$$

$\mathrm{Ni} \quad$ : Ukuran sampel pada kelompok tani ke-i

$\mathrm{Ni}$ : Ukuran populasi ada kelompok tani ke-i

$\mathrm{N} \quad$ : Populasi pada seluruh kecamatan sampel

n : Jumlah sampel yang ditetapkan

Untuk mendapatkan sampel penerima dana bergulir, digunakan teknik simple random sampling.

\section{Metode Analisis Data}

Penelitian ini dilakukan dengan metode survey dan data yang telah diperoleh dilapangan diidentifikasi, diolah dan dianalisa secara deskriptif kualitatif yaitu dengan cara mendeskripsikan fokus kajian yang telah diteliti sehingga dapat menjelaskan kondisi pelaksanaan program PUAP. Hasil analisis pelaksanaan program PUAP dibandingkan dengan pedoman/petunjuk, sehingga dapat diketahui apakah pelaksanaan program tersebut telah sesuai dengan ketentuan atau tidak. Untuk mengevaluasi bagaimana pelaksanaan program PUAP dan penyaluran dana PUAP digunakan matrik analisis kesesuaian. Hasil penelitian ini menunjukkan berapa persen dari masing-masing elemen evaluasi yang dilaksanakan sesuai ketentuan.

\section{Konsepsi Pengukuran dan Variabel}

1. Pengembangan Usaha Agribisnis Perdesaan yang selanjutnya disingkat PUAP adalah bantuan modal usaha Gabungan Kelompoktani dalam 
menumbuhkembangkan usaha agribisnis sesuai dengan potensi pertanian desa sasaran.

2. Petani adalah perorangan Warga Negara Indonesia beserta keluarganya yang mengelola usaha di bidang pertanian yang meliputi usaha hulu, usaha tani, agroindustri, pemasaran dan jasa penunjang.

3. Kelompoktani yang selanjutnya disingkat Poktan adalah kumpulan petani/peternak yang dibentuk atas dasar kesamaan kepentingan, kesamaan kondisi lingkungan (sosial, ekonomi, sumber daya) dan keakraban untuk meningkatkan dan mengembangkan usaha anggota.

4. Gabungan Kelompoktani PUAP yang selanjutnya disingkat Gapoktan PUAP adalah kumpulan beberapa Poktan bekerjasama untuk meningkatkan skala ekonomi dan efisiensi usaha yang menerima dana BLM PUAP.

5. Bantuan Langsung Masyarakat PUAP yang selanjutnya disingkat BLM PUAP adalah dana bantuan modal untuk Gapoktan guna pengembangan usaha agribisnis di perdesaan.

6. Rencana Usaha Bersama yang selanjutnya disingkat RUB adalah rencana usaha untuk pengembangan agribisnis yang disusun oleh Gapoktan berdasarkan kelayakan usaha dan potensi desa.

7. Penyelia Mitra Tani yang selanjutnya disingkat PMT adalah individu yang memiliki kemampuan dan pengetahuan di bidang keuangan mikro yang direkrut oleh Kementerian Pertanian untuk melakukan sosialisasi, advokasi, dan supervisi tentang pengetahuan PUAP kepada pengurus Gapoktan dalam pengelolaan dana BLM PUAP.

8. Indikator keberhasilan output antara lain:

a. tersalurkannya dana Bantuan Langsung Masyarakat (BLM) PUAP 2015 kepada petani, buruh tani dan rumah tangga tani miskin anggota Gapoktan sebagai modal untuk melakukan usaha produktif pertanian; dan

b. terlaksananya fasilitasi penguatan kapasitas dan kemampuan sumber daya manusia pengelola Gapoktan, Penyuluh dan PMT.

9. Indikator keberhasilan outcome antara lain:

a. meningkatnya kemampuan Gapoktan dalam memfasilitasi dan mengelola bantuan modal usaha untuk petani anggota baik petani pemilik penggarap, petani penggarap, buruh tani maupun rumah tangga tani;

b. meningkatnya jumlah petani, buruh tani dan rumah tangga tani yang mendapatkan bantuan modal usaha; dan

c. meningkatnya aktivitas kegiatan usaha agribisnis (hulu, budidaya dan hilir) di perdesaan.

10. Indikator benefit dan Impact antara lain:

a. Berkembangnya usaha agribisnis di perdesaan;

b. berfungsinya Gapoktan sebagai lembaga ekonomi petani di perdesaan yang dimiliki dan dikelola oleh petani; dan

c. berkurangnya jumlah petani miskin dan pengangguran di perdesaan.

HASIL DAN PEMBAHASAN

\section{Gambaran Pelaksanaan Program PUAP}

PUAP (Pemberdayaan Usaha Agribisnis Pedesaan).Adalah bagian dari pelaksanaan program PNPM-Mandiri melalui bantuan usaha gabungan kelompoktani dalam menumbuh kembangkan usaha agribisnis sesuai dengan 
potensi desa sasaran. Adapun tujuan PUAP tersebut adalah unutuk mengurangi kemiskinan dan pengangguran melalui pengembangan usaha agribisnis sesuai potensi wilayah serta meningkatkan pengetahuan dan ketrampilan pelaku usaha agribisnis,pengurus gapoktan ,penyuluh pertanian dan lain-lain. Adapun sasaran puap sendiri adalah meningkatkan perkembangan usaha agribisns di desa terutama desa miskin sesuai dengan potensi pertanian ,serta meningkatkan kesejahteraan rumah tangga tani yang kurang mampu di tingkat pedesaan.

Program PUAP mulai bergulir di Kabupaten Tanjung Jabung Timur sejak tahun 2008 namun realisasi pencairan dana dan kepengurusan lembaga puap dimulai pada tahun 2009. Dana yang diperoleh oleh setiap Gapoktan adalah sebesar Rp.100.000.000., dibagi dengan jumlah kelompok tani. Adapun proses pencairan dana yang dilakukan adalah 60/40 \% setiap enam bulan sekali yang dihibahkan oleh dinas ketahanan pangan Kabupaten Tanjung Jabung Timur pada setiap tahunya melalui Rekening gapoktan setempat di Bank Negri atau Bank Daerah setempat dengan syarat dan ketentuan yang ditentukan.

Dana yang dipinjamkan pada peminjam adalah sebesar Rp.1.000.000.,dengan bunga pengembalian sebesar 0,5\% dengan jangka waktu pengembalian sesuai kesepakatan peminjam dan pengurus Gapoktan setempat di kelurahan masing-masing. Tanaman yang diusahakan petani bermacam-macam, sehingga proses pengembalian dana dilakukan dengan dua versi: versi pertama dilakukan sesuai prosedurial yaitu dengan melakukan angsuran perbulan oleh peminjam kepada bendahara gapoktan selama enam bulan maka pinjaman harus dilunasi oleh peminjam. Versi kedua dilakukan dengan kesepakatan antara peminjam dan pengurus dana yaitu dilakukan angsuran permusim tanam (3 bulan) dan harus dilunasi oleh peminjam dengan $2 \mathrm{x}$ angsuran dengan jangka waktu enam bulan saja untuk petani yang berusahatani tanaman semusim. Adapun persyaratan dan jaminan yang diberlakukan adalah saprodi ,surat -surat berharga dan barang yang bisa dijadikan jaminan untuk pinjaman Finance. Pegelolaan dana puap dikelola oleh pengurus Puap yang di awasi di bawah pengawasan pengurus Gapoktan di tingkat desa. Setelah pengembalian dana puap pada tiap periode diharapkan dapat meningkatkan jmlah alokasi dana hibah dari tahun-tahun sebelumnya, namun kenyataannya berbeda, pengembalian dana puap sering kali lamban dan tidak berjalan mulus sesuai prosedur yang ditentukan hal ini dikarenakan adanya gagal panen (Fuso) yang dialami petani peminjam sehingg adapat menyebabkan stagnansi atau berjalan ditempat tanpa adanya pengembangan dana seperti yang diinginkan dan dicanangkan sesuai program pemerintah setempat.

Dampak program Pemberdayaan usaha Agribisnis Pedesaan memberikan efek positif pada usaha rumah tangga maupun usaha di sektor pertanian karena pelaku usaha dapat menambakan dana usaha dengan bunga yang sangat kecil dengan pengembalian sesuai kemampuan yang ditentukan sesuai kesepakatan bersama diatas materai. Dikelurahan simpang termasuk salah satu Gapoktan yang sukses mengelola dana puap meskipun sering terjadi permasalahan pengembalian dana angsuran secara internal ,namun dapat disikapi dan diselesaikan secara bijaksana sehingga dapat memecahkan permasalahan yang ada sehingga kepengurusan Puap dikelurahan simpang mendapat predikat Kepengurusan Dana Puap terbaik se Kabupten Tanjung Jabung Timur. 
Sesuai peraturan yang ada jika suatu kepengurusan dana Puap berhasil mengembalikan dana Puap dalam jangka waktu lima tahun,maka gapoktan tersebut wajib membentuk badan usaha sendiri yang berbentuk lembaga keuangan dari peralihan dana PUAP (pemberdayaan Usaha Agribisnis Pedesaan) menjadi LKM-A (Lembaga Keuangan Mikro- Agribisnis) yang dikelola oleh Gapoktan dengan membentuk kepengurusan baru di daerah tersebut. LKM-A (Lembaga Keuangan Mikro agribisnis) adalah lembaga keuangan Non Bank yang didirikan dengan tujuan untuk membantu pengembangan usaha -usaha kecil menengah di bidang Agribisnis dengan pemberian modal. Lembaga ini didrikan dari alokasi dana puap yang dan merupakan bagian dari program PNPM-Mandiri yang sistem kepengurusannya lebih ketat dan lebih tertata dengan rapi dari sistem management nya. Hal ini dikarenakan peserta peminjam harus mendaftar menjadi anggota LKM dan harus mebayar iuran pokok sebesar Rp.150.000.,dan administrasi sebesar Rp.30.000,. berikut:

Adapun syarat untuk mendapatkan pinjaman dana LKM adalah sebagai

1. Peminjam harus menyerahkan foto copy ktp

2. Peminjam harus menyerahkan jaminan berupa surat-surat berharga

3. Peminjam harus menjadi anggota LKM

4. Wajib mengikuti Rapat bulanan dan menbayar angsuran

Yang membedakan UAP dan LKM Adalah besaran bunga, jumlah pinjaman dana dan syarat peminjaman dana. LKM-A( Lembaga keuangan mikro Agribisnis) lebih besar dari pada dana Puap yaitu maksimal sebesar Rp.3.000.000., dan pengembalian angsuran sebesar Rp.6,6 \% dan jangka waktu pengembalian hanya satu tahun .

\section{Evaluasi Program dalam Penyaluran Kredit oleh Gapoktan/LKMA Kepada Petani.}

Permasalahan mendasar yang dihadapi petani adalah kurangnya akses sumber permodalan, sehingga PUAP menjadi program yang tepat saat ini. PUAP sebagai bagian dari pelaksanaan program PNPM-Mandiri melalui bantuan modal usaha Gabungan Kelompoktani memiliki salah satu tujuan yaitu untuk meningkatkan kemampuan pengurus Gapoktan dalam operasionalisasinya. disamping itu salah satu sasarannya yaitu berkembangnya Gapokta yang dimiliki dan dikelola oleh petani untuk menjadi kelembagaan ekonomi. Dalam hal ini indikator keberhasilan output berupa tersalurkannya dana BLM PUAP kepada sasaran dan indikator keberhasilan outcome berupa meningkatnya kemampuan Gapoktan dalam memfasilitasi dan mengelola bantuan modal usaha untuk petani anggota baik petani pemilik penggarap, petani penggarap, buruh tani maupun rumah tangga tani. Untuk lebih jelasnya dapat tergambar pada Tabel 1. 
Tabel. Daftar Distribusi Frekuensi Penyaluran Dana PUAP Di Kabupaten Tanjung Jabung Timur Tahun 2016

\begin{tabular}{lllll}
\hline No & \multicolumn{2}{l}{$\begin{array}{l}\text { Kisaran Penyaluran Dana } \\
\text { (Rp.) }\end{array}$} & $\begin{array}{l}\text { Frekuensi } \\
\text { (Gapoktan) }\end{array}$ & $\%$ \\
\hline 1 & $0-$ & 19.999 .999 & 1 & 5.26 \\
2 & $20.000 .000-$ & 39.999 .999 & 0 & 0 \\
3 & $40.000 .000-$ & 59.999 .999 & 0 & 0 \\
4 & $60.000 .000-$ & 79.999 .999 & 13 & 68.42 \\
5 & $80.000 .000-$ & 100.000 .000 & 5 & 26.32 \\
\hline Total & & $\mathbf{1 9}$ & $\mathbf{1 0 0}$ \\
\hline
\end{tabular}

Tabel 1 menunjukkan bahwa penyaluran dana PUAP kepada Gapoktan minimal Rp. 60.000.000ke atas yaitu $68,42 \%$ pada kisaran Rp.60.000.000 79.999.999 dan 26,32\% pada kisaran Rp.80.000.000 - 100.000.000. Hal ini menggambarkan suatu keberhasilan dalam aspek penyaluran dana PUAP ke pihak Gapoktan, terlihat dari data yang menginformasikan hanya satu Gapoktan saja yang tidak mengalami penyaluran dana PUAP dan 94,74\% $(68.42 \%+26.32 \%)$ dana PUAP telah tersalurkan dengan lancar ke Gapoktan sebagai sasaran minimal 60\% (Rp.60.000.000).

Indikator lain yang menggambarkan keberhasilan program ini adalah Indikator benefit dan impact berupa berkembangnya usaha agribisnis di perdesaan, dan berfungsinya Gapoktan sebagai lembaga ekonomi petani di perdesaan yang dimiliki dan dikelola oleh petani.

Tabel 2. Daftar Distribusi Frekuensi Perkembangan Dana PUAP Di Kabupaten Tanjung Jabung Timur Tahun 2016

\begin{tabular}{lllll}
\hline No & \multicolumn{2}{l}{ Kisaran Perkembangan Dana (Rp.) } & $\begin{array}{l}\text { Frek. } \\
\text { (Gapoktan) }\end{array}$ & \% \\
\hline 1 & $0-$ & 5.784 .999 & 14 & 73.68 \\
2 & $5.785 .000-$ & 11.569 .000 & 1 & 5.26 \\
3 & $11.570 .000-$ & 17.354 .999 & 3 & 15.9 \\
4 & $17.355 .000-$ & 23.139 .999 & 0 & 0 \\
5 & $23.140 .000-$ & 100.000 .000 & 1 & 5.26 \\
\hline Total & & $\mathbf{1 9}$ & $\mathbf{1 0 0}$ \\
\hline
\end{tabular}

Perkembangan dana di wilayah penelitian terlihat kurang berhasil, hal ini terlihat sebagaimana Tabel 2 menggambarkan bahwa dana yang berkembang di ata rata-rata hanya terjadi pada satu Gapoktan saja berarti hanya 5,26\% dari Gapoktan yang ada di wilayah penelitian. Sedangkan sisanya 94,84\% Gapoktan belum menunjukkan perkembangan yang memuaskan karena dana yang berkembang masih di bawah rata-rata. Disamping itu ternyata dana PUAP yang tidak mengalami pengembangan (Rp. 0 - Rp. 5.784.999) memiliki frekuensi terbesar yaitu 14 Gapoktan (73.68\%). Berdasarkan data tersebut maka dapat dikatakan bahwa dana PUAP di Kabupaten Tanjung Jabung Timur belum berkembang dengan baik. Hal ini perlu mendapatkan perhatian yang lebih dari pemerintah untuk mencari kendala yang masih ada. 
Tabel 3. Daftar Distribusi Frekuensi Persentase Perkembangan Dana PUAP Di Kabupaten Tanjung Jabung Timur Tahun 2015

\begin{tabular}{lllll}
\hline No & $\begin{array}{l}\text { Kisaran } \\
\text { Perkembangan Dana } \\
(\%)\end{array}$ & Persentase & $\begin{array}{l}\text { Frekuensi } \\
\text { (Gapoktan) }\end{array}$ & $\%$ \\
\hline 1 & $0-$ & 5.78 & 13 & 68,42 \\
2 & $5.79-$ & 11.57 & 1 & 5.26 \\
3 & $11.58-$ & 17.36 & 3 & 15.79 \\
4 & $17.37-$ & 23.15 & 0 & 0 \\
5 & $23.16-$ & 28.93 & 2 & 10.53 \\
\hline Total & & $\mathbf{1 9}$ & $\mathbf{1 0 0}$ \\
\hline Rata-rata & $\mathbf{1 7 . 3 6}$ & & \\
\hline
\end{tabular}

Perkembangan dana di pihak lain dapat dilihat dari segi persentase pengembalian sebagaimana dilihat pada Tabel 3. Terlihat masih banyak Gapoktan yang belum dapat mengembalikan bantuan ini yaitu 68,42\% Gapoktan. Sedangkan yang dapat mengembalikan dana di atas rata-rata sebesar $23.16 \%$ $28.93 \%$ hanya 2 (dua) Gapoktan saja, dan sisanya menunjukkan persentase di bawah rata-rata.

\section{KESIMPULAN DAN SARAN Kesimpulan}

Berdasarkan uraian di atas dapat disimpulkan beberapa kondisi bahwa program PUAP mulai bergulir di Kabupaten Tanjung Jabung Timur sejak tahun 2008 yang dikucurkan untuk 16 desa dengan total dana sebesar Rp. 1.600.000.000,- Rata-rata dana PUAP dari pemerintah sebesar Rp. 100.000.000,per Gapoktan dengan rata-rata penyaluran per Gapoktan 60.000.000,-. Setiap gapoktan memiliki jumlah anggota yang berbeda dengan besar penyaluran yang berbeda pula. Proses pengembalian dana dilakukan dengan mencicil ditambah uang jasa $0.5 \%$ dari pinjaman per bulan.

Proses penyaluran kredit oleh Gapoktan/LKMA kepada petani dapat dikatakan berhasil dengan adanya penyaluran yang mayoritas sudah mencapai Rp.60.000.000 ke atas, tetapi belum berhasil dalam perkembangan dananya.

Saran

Dari fenomena yang ada terlihat masih banyaknya kendala dalam sistem pengembalian dana dan dinyatakan belum berhasil terutama disebabkan oleh masih banyaknya petani yang mengalami gagal panen, maka kendala kegagalan ini harus menjadi fokus perhatian bagi pemangku kebijakan untuk turut menanggulanginya. Dengan demikian dapat membantu memperlancar sistem pengembalian, dan perkembangan dana PUAP.

\section{DAFTAR PUSTAKA}

Badan Pusat Statistik, 2016.Persentase Penduduk Miskin Maret

2015.http://www.bps.go.id/brs/view/1158 diakses tanggal 17 Februari 2016

Desi Kamira dkk, 2011. Evaluasi Pelaksanaan Program Pengembangan Usaha Agribisnis Perdesaan (Puap) Di Kota Padang http://pasca.unand.ac.id/id/wp-content/uploads/2011/09/EVALUASIPELAKSANAAN-PROGRAM-PUAP.pdf diakses pada tanggal 14 Februari 2016 
Dinas Pertanian Kabupaten Tanjung Jabung Timur, 2015. Daftar Rekapitulasi Penyaluran Dana PUAP Tahun Peluncuran 2012 Kabupaten Tanjung Jabung Timur.

Elina Situmorang dkk, 2010.Ringkasan Eksekutif Hasil-hasil Penelitian 2010. http://www.litbang.pertanian.go.id/ks/one/633/file/293-294-EVALUASIKEBERHASI.pdf Diakses pada tanggal 14 Februari 2016

Kementerian Pertanian. 2015. Peraturan Menteri Pertanian Republik Indonesia Nomor 06/Permentan/Ot.140/2/2015 Tentang Pedoman Pengembangan Usaha Agribisnis Perdesaan http://www.pertanian.go.id/assets/upload/doc/Permentan_06_2015_Pedoma n_PUAP_2015.pdf Diakses pada tanggal 15 Februari 2016

Kementerian Keuangan. 2015. Permenkeu no.99/PMK.05/2008 http://www.kemenkeu.go.id/node/20697 diakses pada tanggal 16 Februari 2016.

Rodjak A. 1996. Dasar-dasar Manjemen Usahatani. Fakultas Pertanian UNPAD. Bandung.

Soekartawi. 2006. Pengantar Agribisnis. PT. Raja Grafindo Persada. Jakarta. 